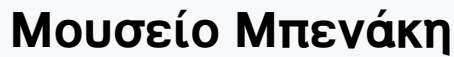

Tóp. 1, Ap. 11-12 (2012)

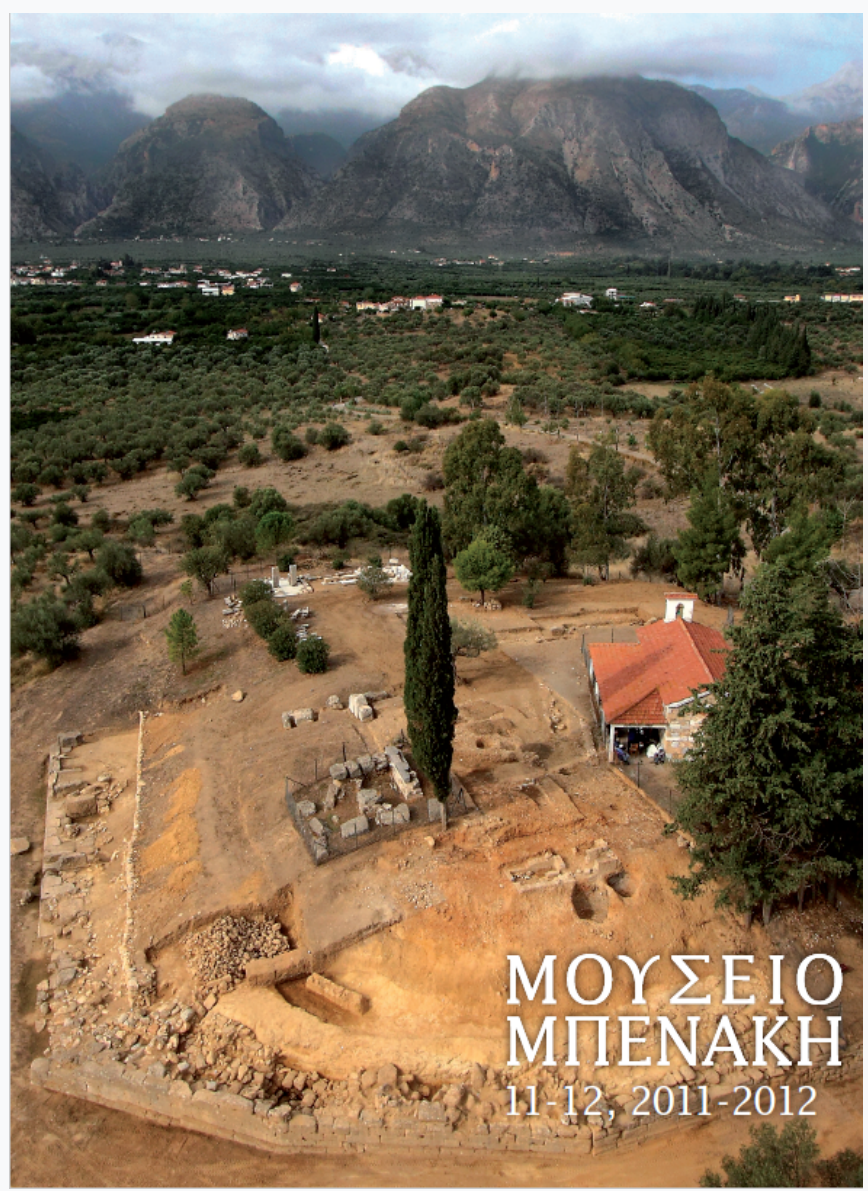

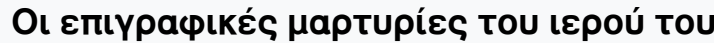

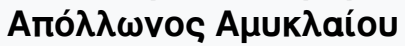

Eleni Zavvou, Athanassios Themos

doi: $\underline{10.12681 / \text { benaki.17804 }}$

Copyright $\odot$ 2018, Eleni Zavvou, Athanassios Themos

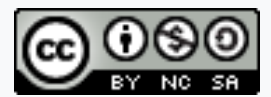

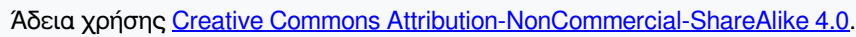

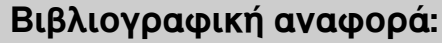

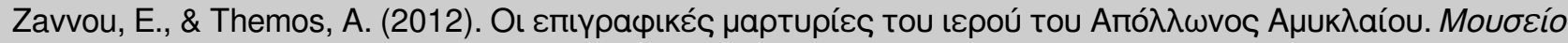

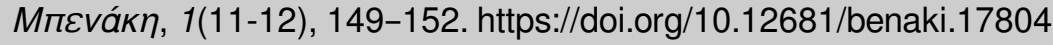




\section{The Epigraphic Evidence of the Sanctuary of Apollo Amyklaios}

HIE PRESERVED EPIGRAPHIC EVIDENCE of the sanctuary of Apollo Amyklaios is not great in quantity, ${ }^{1}$ but significant. The aim of our work ${ }^{2}$ is to re-examine the inscriptions of the sanctuary and to find those which are published but we no longer know where they are located. The second aim is the collection and classification of the literary sources about the sanctuary and its operation.

The sanctuary of Apollo Amyklaios was one of the most important cult centres of the Lacedaimonians. From Thucydides it is known that the sanctuary was a place for the erection of stelai with texts of political significance (Thuc. V.18.10), such as the stele with the text of the Peace of Nikias in 422/1 BC (Thuc. V.23.4-5). The sanctuary and the festival of Hyakinthia were also chosen by Lacedaimonians as the venue for the exchange of the oaths with the Argives for the proposed treaty of $420 \mathrm{BC}$ (Thuc. V.41.3). The same sanctuary is considered by Matthaiou and Pikoulas as the place for the erection of the stele inscribed with a list of contributions to Sparta (IGV1, $1+$ SEGXXXIX 370) either in money or in kind, made both by cities and individuals during the Peloponnesian war. ${ }^{3}$

Inscriptions that could be attributed to the sanctuary of Apollo Amyklaios were recorded by the French Abbé Michel Fourmont in the early 18th century. However, Fourmont, who did not know the exact location of the sanctuary of Apollo, attributed wrongly to it many inscriptions, such as $I G \mathrm{~V} 1596$ and 605, which seem to come from the sanctuary of Demeter and Kore at Kalyvia Sochas. ${ }^{4} \mathrm{He}$ also attributed to the Amyklaion an inscription (IGV1, 515) which is forged, as Spawforth proved. ${ }^{5}$ Few inscribed monuments were found during the first excava- tions at the site and a short number of inscriptions were added in the latest years.

From the sanctuary of Apollo may have originated parts of catalogues of officials of the Roman period found by Fourmont (IGV 1, 40, 75 and perhaps 161) at the areas of Godena and Sklavochori. One of these is stored at the Sparta Archaeological Museum. ${ }^{6}$ Recent research of the architectural members of the sanctuary has proven that one more catalogue comes from it. It is a catalogue of Gerontes of the time of Antoninus Pius, written on a column (IGV 1, 112 = Sparta Archaeological Museum, inv. no. 208). ${ }^{7}$

Part of a catalogue is also preserved on a fragment of a Laconian roof tile with brown glaze, a surface find at the site of the Amyklaion. ${ }^{8}$ It can be dated perhaps to the second half of the 3th century $\mathrm{BC}$ and preserves parts of twelve female names, incised on the surface of the tile after its firing. According to Edmonson, editor of the inscription, the list of women's names could have had ritual or religious significance, since women played an important role in the festival of Hyakinthia ${ }^{9}$ as it is shown by the literary sources. ${ }^{10}$

Among the votive offerings of private or public character, dedicatory inscriptions cut on bronze ${ }^{11}$ or stone objects are included. Among the dedications on stone there is a fragmentary stele of 5th century $\mathrm{BC}$ dedicated perhaps by an athletic victor, bearing a list of the contests he won according to Jeffery's restoration. ${ }^{12}$ There is also part of a dedication of the second half of the 4th century BC, the re-examination of which led to the conclusion that it could be attributed to the back of a throne dedicated to the sanctuary by a member of the gerousia of Classical Sparta. ${ }^{13}$ 
Finally, a base of a dedication of Roman times (1st c. AD?) is preserved. ${ }^{14}$

Two inscribed relief stelai come also from the sanctuary. One of them had two bands with relief decoration, completely chipped away since antiquity. The cult statue (xoano) of Apollo and a sacrifice of a bull on the altar was depicted at the upper band, and a chorus of women on the lower band. ${ }^{15}$ Two lines of an inscription are preserved below the lower band, mentioning names which are considered to be $\sigma \tau a \tau o i$, officials of police function. ${ }^{16}$

The second fragmentary stele preserves the relief of a discus thrower from whom it is preserved part of his chest and his raised left hand (c. 470 BC).${ }^{17}$ Von Massow identified the relief fragment as a part of the stele of Ainetos, a pentathlete who died while he was crowned for his victories at Olympia, seen by Pausanias at the sanctuary (Paus. III.18.7). The stele also preserves a part of a metrical inscription, which seems to refer to multiple victories. ${ }^{18}$

Honourary monuments for priests and priestesses and other members of the Spartan elite were erected at the site during the Roman period, showing the importance of the sanctuary and the festival of Hyakinthia, such as the hon-

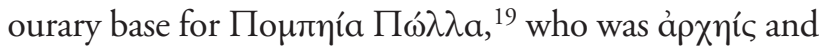
$\theta \varepsilon \omega \rho$ ó $\varsigma$ of the Hyakinthia, and the honourary bases for Tıß́́pı Pouprívoc, son of $\mathrm{Y}^{\prime} \varepsilon^{\prime}$ vivo $^{21}$ and a fragmentary honourary base with a metrical inscription. ${ }^{22}$ In one instance, honours were paid to Aelius Ceasar, son of Marcus Aurelius and Faustina the younger, if it is true that the monument copied by Fourmont originated from Amyklaion. ${ }^{23}$ Among the inscriptions of the Roman period there is also a commemorative inscription (titulus memorialis). ${ }^{24}$

Another type of inscriptions are the graffiti of the end of the 6th century BC, ${ }^{25}$ made on the architectural blocks from the throne of Apollo by masons, as it is conjectured by their location at the non visible parts of the blocks. Among them there are masons' names, such as Té $\chi v a \rho \chi o{ }^{26}$ and $\Gamma \lambda a \tilde{x} \chi{ }^{27}$
A few graffiti on sherds and fragments of tiles have been published by Tsountas and Amyx. ${ }^{28}$ Most of them pre-

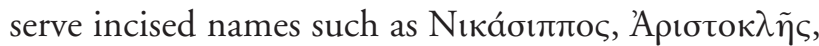

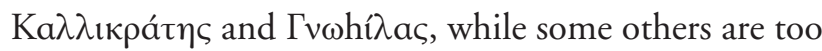
fragmentary to distinguish the type of the inscriptions. Some of these graffiti belong to the 5 th century $\mathrm{BC}^{29}$ while the others to the Hellenistic period.

There is also a considerable number of stamped tiles ${ }^{30}$ which led to the identification of the ancient remains with the sanctuary of Apollo Amyklaios. ${ }^{31}$

Among the 'new' finds ${ }^{32}$ of the sanctuary is the lower part of an inscription written probably on a herm ${ }^{33}$ which we located during our work at the Museum of Sparta. The stone had been used as a pilaster of the entrance of the church of Agia Kyriaki and transferred to the Museum in 1907. It preserves the lower part of an honourary inscription and can be dated after the Constitutio Antoniniana, as is evident from the praenomina and the gentilicia of the

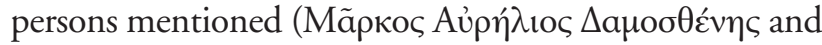

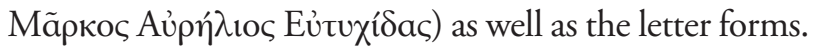

A new fragment was also added to a base copied by Leake at Agia Kyriaki. ${ }^{34}$ It preserves a catalogue of officials of the 3rd century AD.

During the recent excavations at the sanctuary of Apollo Amyklaios, the lower part of a herm was found. ${ }^{35}$ Its back side was cyclical shaped and we joined it with the already known part of the herm of the 3rd century AD, erected in honour of Sekstus Eudamus, son of Sekstus Pompeius Onasikrates, one of the latest members of the Spartan aristocracy. ${ }^{36}$ The inscription preserves the cursus honorum of Sekstus Eudamus who had been high priest of the imperial cult, priest of Zeus and of many other gods, agonothetes of the Dioskouria and the Leonidaia festivals and xystarches of the Hyakinthia festival.

Eleni Zavvou - Athanassios Themos elthe963@otenet.gr 
1. Inscribed monuments have been found during the excavations conducted in the area since late 19th century, while others found rebuilt in modern buildings around the hill.

2. Both of us would like to thank Angelos Delivorrias, the Director of the Benaki Museum, for entrusting us with this task and Mrs A. Panagiotopoulou, A. Vasilogambrou, and A. Papademetriou, former Directors of the 5 th Ephorate of Prehistoric and Classical Antiquities for their help during our work. The present paper has been written by Eleni Zavvou.

3. Matthaiou - Pikoulas 1989, 115. S.M. no. $6656 a+\beta$.

4. See the paper of P. Matalas in the present volume.

5. Spawforth 1976, 139-45.

6. Sparta Archaeological Museum, inv. no. $1215 \mathrm{a}-\mathrm{b}=I G \mathrm{~V}$ 1, 40 and SEG XI, 482. Among the names of the catalogue, the

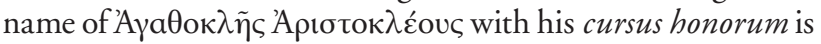
preserved.

7. See the paper of G. Kokkorou-Alevras in the present volume.

8. The tile fragment is kept at the Collection of the American School of Classical Studies at Athens.

9. Edmonson 1959, 162-64 (= SEG XVII, 187). For the participation of women in the Hyakinthia and the consideration of the festival as an initiatory rite see Calame 1997, 175-77; Pettersson 1992, 14, 38; Richer 2004b, 402-03.

10. Polycrates apud Athenaeus IV.139ff.

11. Bronze discus (National Archaeological Museum, inv. no. X8618 = SEG XI, 697): ă $\varepsilon<\theta>\lambda$ ov A $\mu$ $<\kappa \lambda<1>$ aíor. Bronze handle of vase, late 7th-early 6th c.? BC (SEG XI, 689; Jeffery

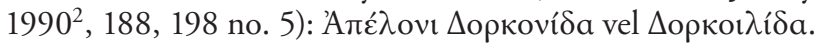
Fragment of bronze helmet, 600-550? (SEG XI, 690; Jeffery

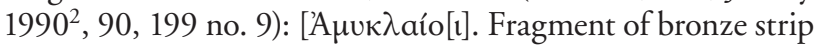
(SEG XI, 691a): [А $\mu \nu \kappa] \lambda$ aíor. Fragment of bronze strip (SEG

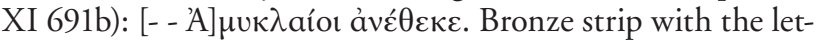
ters TPI (National Archaeological Museum, inv. no. X $8120=$ Tsountas 1892, 17 (= IG V1, 846 and SEG XLII 301).

12. Sparta Archaeological Museum, inv. no. $2623=$ Buschor - Von Massow 1927, 61 = SEG XI, 693. See also the restoration proposed by Jeffery $1990^{2}, 193$ n. 4 .

13. Sparta Archaeological Museum, inv. no. 938, see Skias 1919, 34 no. 8 (= SEG I 87); Fiechter 1918, 223 no. 12. For the attribution of the marble fragment to the back of a throne, dedicated by a member of the Spartan gerousia see Zavvou 2013, 93-104.

14. Sparta Archaeological Museum, inv. no. 942, see Skias 1919, 34 no. 9 (= SEG I, 88).

15. Sparta Archaeological Museum, inv. no. $689=9101$

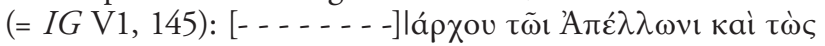

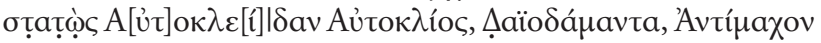
Táoкou. For the relief stele see Tsountas 1892, 8-9; Schröder 1904, 24-31; Tod-Wace 1906, 80, 202, no. 689; Metzger 19421943, 236; Calame 1997, 177 n. 274.275. The inscription had at least one more line in the beginning which has been chipped away.

16. Anecdota Graeca (ed. I. Bekker), 305, no. 20: $\sigma \tau a \tau \tilde{\omega} \nu$.

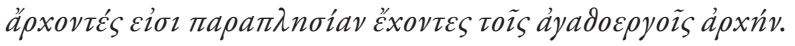

17. Sparta Archaeological Museum, inv. no. 940. The stele was revealed during the excavations conducted by Fiechter in 1907. It was mentioned by Versakis who considered it as part of the Throne of Apollo Amyklaios and identified the relief as the shoulder of an animal but he did not mention the inscription, see Versakis 1912, 188, fig. 16. The identification of Versakis was rejected by Skias who mentioned the inscription and read some of its letters, see Skias 1919, 32-33. A drawing of the inscription was given by Fiechter 1918, 220 no. 2 and abb. 74, 222 , abb. 84 . The identification with the stele of Ainetos was made by von Massow 1926, 41-47 = SEG XI, 696 = BE in $R E G$ 41 (1928), 368-69. For the stele see also Despinis 2013, 17-18.

18. According to Hiller von Gärtringen the stele preserves

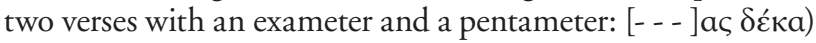
$\kappa a<i>$ hevatov | [- - $\kappa \varepsilon[--]$; the numerals $\delta \varepsilon ́ \kappa a$ and ह̌vatos may refer to the value of the prizes, or the age of the athlete or the number of his victories. Gärtringen also proposed the restoration of the word $[\mu v] \tilde{\mathrm{a}} \varsigma$ in the beginning of the inscription, see Hiller von Gärtringen apud von Massow 1926, 43. A list of victories (?) is also identified by Jeffery $1990^{2}, 195,201$ no. 51 .

19. $I G \mathrm{~V} 1,587$. The base is still to be found in the area of the sanctuary.

20. IG V1, 497 (Sparta Archaeological Museum, inv. no. 691=10582).

21. Cook 1950, 281-82.

22. $I G \mathrm{~V} 1,455=$ SEG XI 772 (Sparta Archaeological Museum, inv. no. 690).

23. IG V1, 446 (Sparta Archaeological Museum, inv. no. 1214).

24. Sparta Archaeological Museum, inv. no. $879=945$. SEG I 89.

25. For the date see Jeffery $1990^{2}, 194,200$ no. 32.

26. $I G \mathrm{~V} 1,823$.

27. IG V1, 832a (Sparta Archaeological Museum, inv. no. 10561).

28. Tsountas 1892, 4 (= IG V1, 1574); Amyx 1957, 168-69 (= SEG XVII, 188). Some sherds, published by Tsountas, are consindered as fragments of tiles by Amyx.

29. Tsountas 1892, 4: no. 3 because of the three-bar sigma and the closed type of the aspirate letter; no. 4 because it is written in retrograde with archaic looking letters and has a longtailed epsilon and a closed aspirate. For the date of these sherds see also Amyx 1957, 169.

30. Sparta Archaeological Museum, inv. nos 635-646, 947, $948=I G$ V1 863, IG V1 1515c and Krentz 1989, 315 n. 13 (= SEGXXXIX 371).

31. Tsountas $1890,37$. 
32. All the 'new' inscriptions will be published soon.

33. Sparta Archaeological Museum, inv. no. 943.

34. $I G \mathrm{~V} 1,523$ = Sparta Archaeological Museum, inv. no. 941.
35. See the paper of S. Vlizos at the present volume.

36. $I G \mathrm{~V} 1,559$ = Sparta Archaeological Museum, inv. no. 544. New fragment: Sparta Archaeological Museum, inv. no. 16751. The two fragments were joined by E. Zavvou.

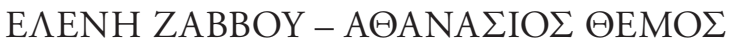

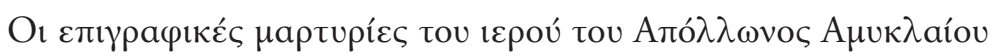

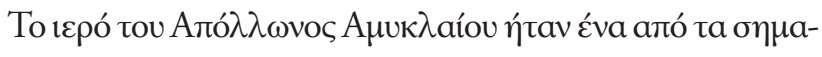

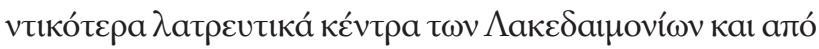

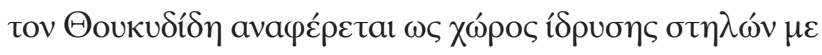
кв́́

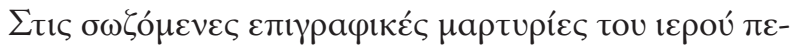

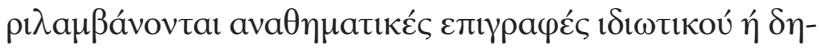

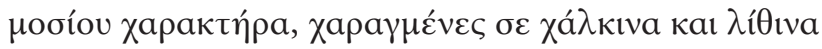

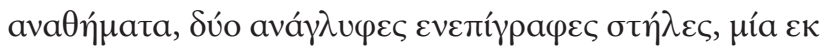

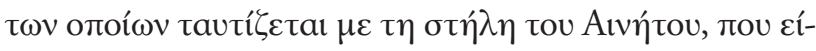

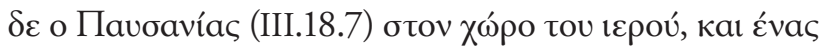

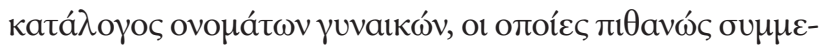

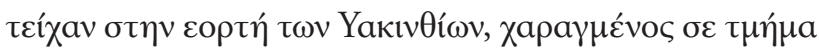

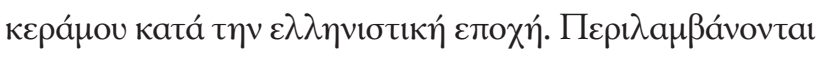

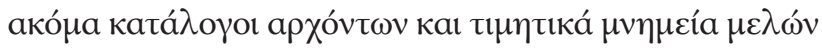

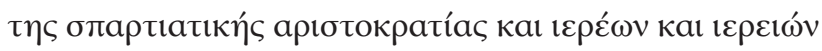

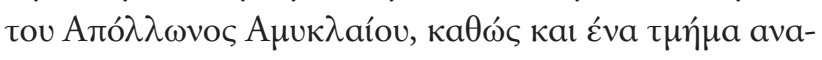

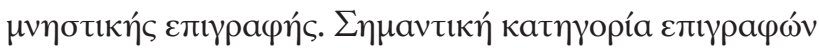

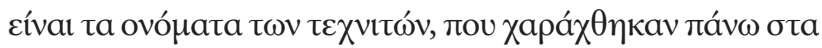

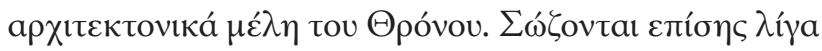

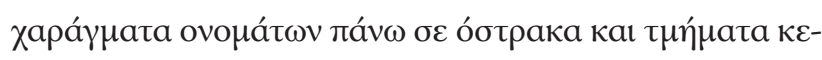

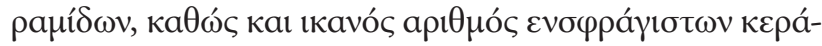

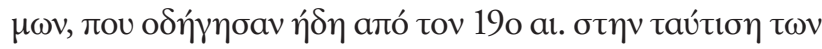

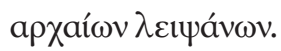

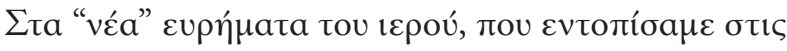

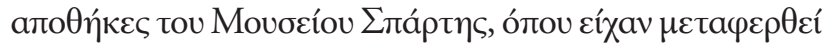

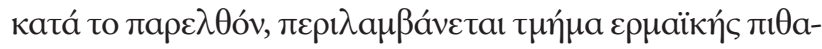

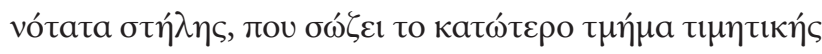

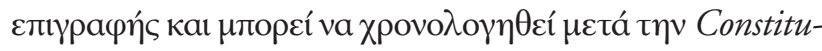

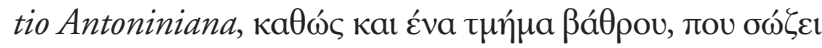

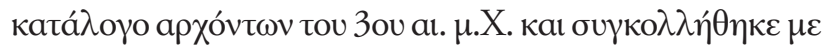

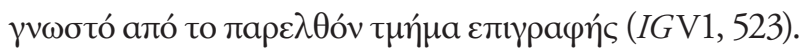

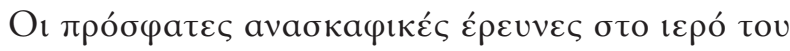

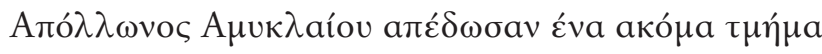

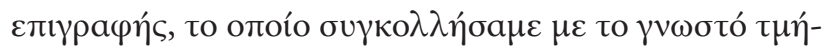

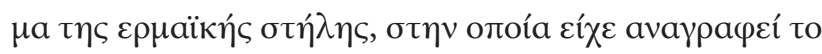

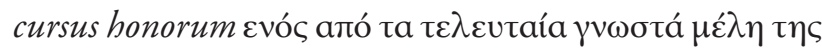

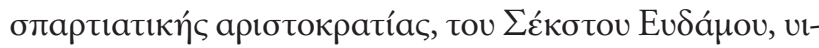

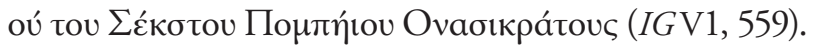

